\title{
COMBRETACEAE OF THE 1936 ARCHBOLD EXPEDITION (FLY RIVER, BRITISH NEW GUINEA)
}

\author{
A. W. ExelL
}

Combretum trifoliatum Vent., Choix de Pl. t. 58 (1808).

Western Division: Middle Fly River, Lake Daviumbu, fl. Sept. 1936, L. J. Brass 7709, rain-forest; large scrambling shrub, plentiful on shores of lake.

This species is widespread in the Indo-Malayan region from Assam and Indo-China to New Guinea, but it is apparently absent from the Philippines. The specimen collected extends the known range of the species southwards, as the only other New Guinea records are from the Sepik region in the north-east, in the former German colony.

Quisqualis indica L., Sp. Pl. ed. 2, 1: 556 (1762).

Western Division: Lower Fly River, east bank opposite Sturt Island, fl. Oct. 1936, L. J. Brass 8198, scrambling on river-banks and commonly climbing to the tops of tallest forest-trees; flowers white, later red.

This species, often cultivated in the tropics, is indigenous in the IndoMalayan region and undoubtedly wild in New Guinea.

Terminalia Catappa L., Mant. 1: 128 (1767).

Western Division: coast between Oriomo and Fly Rivers, fl. March 31, 1936, L. J. Brass 6416, one of the chief components of beach-forests; large spreading tree with thick tessellate bark; flowers white.

Widespread coastal species in the Indo-Malayan and Polynesian regions; often planted in other parts of the Tropics.

Terminalia Copelandii Elm., Leaflets Philipp. Bot. 5: 1759 (1913).

Western Division: Lower Fly River, east bank opposite Sturt Island, fl. Oct. 1936, L. J. Brass 8027, very conspicuous flat-topped tree towering above general level of the flood-plain forests; trunk heavily buttressed; bark thick, brown, long-fissured, peeling in small suberose scales; wood brown, tough; flowers white; tree bare of leaves in Sept.Oct.

If this is correctly identified it is an interesting discovery of a species hitherto known, as far as I am aware, only from Palawan, Philippine 
Islands, where it grows in the coastal forests, presumably in very similar conditions to those in which it was found growing by Brass in Papua. The leaves, inflorescences and twigs agree very well with the Palawan species but in the absence of fruit, often of great taxonomic value in this genus, the identification must remain doubtful.

Terminalia cf. Kaernbachii Warb. in Bot. Jahrb. 18:201 (1893), ex descr.

Western Division: Palmer River, two miles below the junction of Black River, fr. June, 1936, L. J. Brass 6973, common, very conspicuous tree in riverine forests, $35 \mathrm{~m}$. tall, straight bole, flange-buttressed base; bark grey flaky, inner purplish; leaves at ends of branchlets; fruits red, fleshy, sessile, solitary on peduncle.

I have seen no specimen of T. Kaernbachii but Brass 6973 agrees well with the description except that the fruit is a little smaller than in T. Kaernbachii $(6.5 \mathrm{~cm}$. long instead of $8 \mathrm{~cm}$. long) and more flattened. Terminalia Kaernbachii is endemic to New Guinea.

Terminalia aff. edulis Blanco, Fl. Filip. ed. 2, 265 (1845).

Western Division: two miles below junction of Black River, fr. June, 1936, L. J. Brass 6970, tree $20 \mathrm{~m}$., leaves thin, red when old, fruit green, compressed, about $2 \mathrm{~cm}$. long, $1 \mathrm{~cm}$. in diam.; same locality, fr. July, 1936, L. J. Brass 7288, principal primary forest tree on sandy silt-loams of river flood-plains, up to $30 \mathrm{~m}$. tall with well-developed flank-buttresses; bark thin, fibrous, suberose, with vertical furrows; same locality, fl. July, 1936, L. J. Brass 7350 , abundant in forests of lower ridges; large semi-deciduous canopy-tree; trunk spur-buttressed; bark brown, thin, flaky, wood pale, of cedar-like appearance, leaves, (still young) concave; flowers white; Fly River, between junctions of Alice and Elevata Rivers, fr. Aug., 1936, L. J. Brass 7388, semi-deciduous tree attaining to $20 \mathrm{~m}$., on river-banks.

These specimens show a close general resemblance to T. edulis Blanco, a common species in the Philippine Islands. The Papuan specimens, however, have a sparser indumentum at all stages, the leaves, petioles and twigs becoming practically glabrous. Collections from intermediate regions are required to show whether the range and variation are discontinuous or not.

Terminalia hypargyrea Laut. \& K. Schum., Fl. Deutsch. Schutzgeb. Südsee, 467 (1901).

Terminalia sogerensis Bak. f. in Jour. Bot. 61, Suppl.: 14 (1923).

Western Division: Middle Fly River, Lake Daviumbu, fl. Sept., 
1936, L. J. Brass 7782, rain-forest, occasional near shores of lake; tree with spur-buttressed stem; bark thin, brown, exfoliating in thin suberose flakes; Lower Fly River, Gaima, fr. Nov., 1936, L. J. Brass 8315, substage tree $12 \mathrm{~m}$. high, in light rain-forest; bark thin, suberose, slightly fissured; fruit red, compressed; Wassi Kussa River, Tarara, fr. Dec., 1936, L. J. Brass 8551, gallery extensions of rain-forest; tree 10-12 m.; branches horizontal; bark hard, fissured; wood yellow; fruit red, fleshy, covered with purplish bloom.

Endemic to New Guinea.

Terminalia cf. complanata K. Schum. \& Hollr., Fl. Kais. Wilh. Land, 83 (1889).

Western Division: Daru Island, fr. April, 1936, L. J. Brass 6433, uncommon in rain-forest canopy-layer; large spur-buttressed tree, $20 \mathrm{~m}$. high, spreading crown; bark yellow-brown, laminated, fibrous within, very thin pale brown outer corky later, wood tough, fibrous, stains paper yellow.

This differs from typical $T$. complanata in having a persistent ferruginous-sericeous indumentum on the branchlets and lower surfaces of the leaves. Terminalia complanata shows traces of a similar indumentum on the young parts but is rapidly glabrescent.

Terminalia complanata has been recorded from New Guinea and the Solomon Islands.

Terminalia crassifolia Exell, sp. nov.

Arbor ad $8 \mathrm{~m}$. alta, ramulis 4-6 mm. in diam. crassis primo pubescentibus demum glabrescentibus. Folia ad apicem ramulorum conferta, petiolata, petiolo \pm applanato, 7-13 $\mathrm{mm}$. longo, primo sericeo demum appresse puberulo, lamina subcoriacea obovata apice rotundata nonnunquam breviter apiculata basi plerumque cuneata paullo inaequilaterali, 6-11 $\times 3.5-7.5 \mathrm{~cm}$., supra minute inconspicue pustulata ceteroque glabra subtus ad nervos sparse appresse puberula ceteroque fere glabra, costa media subtus prominente, nervis lateralibus utrinque 9-11. Flores sessiles in spicas axillares ad $11 \mathrm{~cm}$. longas dispositi, rachi pubescente. Receptaculum superius campanulatum (lobis inclusis) $3.5 \times 2.5 \mathrm{~mm}$, glabrescens, lobis (sepalis) deltoideis, $1.3 \times 1.3 \mathrm{~mm}$., glabris, inferius $2 \mathrm{~mm}$. longum dense sericeum. Discus $4.5 \mathrm{~mm}$. in diam. dense pilosotomentosus. Stamina 10, antheris subglobosis, $0.8 \mathrm{~mm}$. in diam., filamentis $3 \mathrm{~mm}$. longis. Stylus $4 \mathrm{~mm}$. longus. Fructus ellipsoideus leviter compressus, in sicco $1.2-1.3 \times 7-8 \mathrm{~mm}$., primo dense demum sparse appresse puberulus. 
Western Division: Mabaduan, fl. \& fr. April, 1936, L. J. Brass 6478 (Typus in Herb. Mus. Brit.), common in light rain-forests on granite slope, densely foliaged, horizontally branched tree, 6-8 m. tall, ripe fruit dark purple, somewhat compressed $\pm 1.5 \mathrm{~cm}$. long, $1 \mathrm{~cm}$. in diam.; Mabaduan, young fr., April, 1936, L. J. Brass 6527, common in savannah-forest substage; small tree, $7-8 \mathrm{~m}$. high; unripe fruit compressed, minutely puberulent.

This species is very near to T. Muelleri Benth. from Queensland and the islands in the Gulf of Carpentaria. It differs in having a sericeous lower receptacle (glabrous in the Australian species) and slightly smaller fruits.

\section{Terminalia sp.}

Western Division: Lower Fly River, east bank, opposite Sturt Island, fl. Oct., 1936, L. J. Brass 8048, rain-forest; large spur-buttressed tree, common on lower ridges; bark brown, flaky-scaly, yellow when cut; wood yellow; flowers green; branchlets and petioles glaucous.

This is apparently a new species but I do not care to describe it without fruits. The leaves are similar to those of T. papuana Exell (but with longer petioles) and of $T$. solomonensis Exell.

Lumnitzera littorea (Jack) Voigt, Hort. Suburb. Calc. 39 (1845).

Pyrrhanthus littoreus Jack, Malay. Misc. II, 7: 57 (1822).

Western Division: Daru Island, fl. 29 Feb., 1936, L. J. Brass 6228, open places in better-drained parts of mangroves; shrub or small tree to 5 m.; bark rough, reddish brown; flowers white; Wassi Kussa River, Tarara, fl. \& fr., Jan., 1937, L. J. Brass 8691, common small tree in mangroves; bark rough, fissured; flowers red.

This species occurs in mangrove-formations in tropical Asia, tropical Australia and Polynesia.

British Museum, Natural History, LONDON. 


\section{$2 \mathrm{BHL}$ Biodiversity Heritage Library}

Exell, A W . 1939. "Combretaceae of the 1936 Archbold Expedition (Fly River, British New Guinea)." Journal of the Arnold Arboretum 20(3), 317-320. https://doi.org/10.5962/p.325781.

View This Item Online: $\underline{\text { https://www.biodiversitylibrary.org/item/33596 }}$

DOI: https://doi.org/10.5962/p.325781

Permalink: https://www.biodiversitylibrary.org/partpdf/325781

\section{Holding Institution}

Missouri Botanical Garden, Peter H. Raven Library

\section{Sponsored by}

Missouri Botanical Garden

\section{Copyright \& Reuse}

Copyright Status: In copyright. Digitized with the permission of the rights holder.

Rights Holder: Arnold Arboretum of Harvard University

License: http://creativecommons.org/licenses/by-nc-sa/3.0/

Rights: https://biodiversitylibrary.org/permissions

This document was created from content at the Biodiversity Heritage Library, the world's largest open access digital library for biodiversity literature and archives. Visit BHL at https://www.biodiversitylibrary.org. 